Original Article

\title{
COMPARISON OF AMINO ACIDS IN 8 DIFFERENT BOILED TROPICAL FRUITS
}

\author{
RADHA PALANISWAMY*, DHANYASRI SELVARAJ, SANDHIYA RENGANATHAN
}

Department of Biotechnology, Dr. NGP Arts and Science College, Coimbatore 641048

Email: palaniswamyradha@gmail.com

Received: 16 Oct 2018, Revised and Accepted: 10 Dec 2018

\begin{abstract}
Objective: To determine the protein quality, especially the amino acid content of 8 tropical fruits both raw and boiled samples. Eight different tropical fruits were used in the study (Apricot, Jamun, Dragonfruit, Pomegranate, Mangustan, Litchi, Jackfruit, and Kiwi.
\end{abstract}

Methods: Ninhydrin method was used for the estimation of the concentration of amino acids present in the above fruits. Raw and boiled fruits were used for the study.

Results: Both raw and boiled forms which showed thats Jamun and Mangustan contained highest concentration amino acids whereas apricot shows the lowest concentration of amino acids except in Jamun which showed higher values in the raw fruit whereas in others the boiled samples showed higher values.

Conclusion: It was evident that tropical fruits have a good balance of the essential amino acids (both raw and boiled fomr) which provide significant sources of protein in our diet.

Keywords: amino acids, ninhydrin, apricot, jackfruit, Dragon fruit, Pomegranate, Mangustan, Litchi, Jamun, Kiwi

(C) 2019 The Authors. Published by Innovare Academic Sciences Pvt Ltd. This is an open-access article under the CC BY license (http://creativecommons.org/licenses/by/4.0/) DOI: http://dx.doi.org/10.22159/ijcpr.2019v11i1.31995

\section{INTRODUCTION}

The amino acid content of fruit and fruit-derived foods is studied intensely because of the contribution to nutritional value, aroma, taste and health-promoting effects. The fruit contains a wide range of nutritional and medicinal components, such as vitamins, minerals, amino acids, and polysaccharides [1]. It is believed to have valuable senescence-retarding and cancer-preventative effects [2]. Numerous functional foods and health care products for clinical applications have been developed from the fruit or its organic extracts. Recent studies show that some fruits contain a relatively high quantity of protein. This potential protein source has been indicated by the crude protein content of their edible portion [3]. Scarce work has been done to determine the protein quality, especially the amino acid content of several tropical fruits which paved way for the current study.

Fruits used in this study includes the following Apricot, Jamun, Dragonfruit, Pomegranate, Mangustan, Litchi, Jackfruit, Kiwi. Apricot (Prunus armeniaca) of the family rosaceae is popular regulating blood pressure and cholesterol and abundance of vitamin A [4] Jamun (Syzygium cumini L.) is a polyembryonic species (family Myrtaceae) rich in anthocyanins and exhibits good antioxidant characteristics [5]. Dragonfruit (Hylocereus polyrhizus) from Latin America (Cactaceae family) is rich in vitamin C, calcium and phosphorus, and known for its fiber content [6]. The pomegranate (Punica granatum) an ancient, mystical, and highly distinctive fruit (Punicaceae family) has the potential therapeutic properties of treatment and prevention of cancer, cardiovascular disease, diabetes, dental conditions, and protection from ultraviolet (UV) radiation [7]. Mangostan (Garcinia mangostana L.) (Hypericaceae was alternatively known as Clusiaceae and Guttiferae) is a tropical evergreen tree, originated in the Sunda Islands is known for for treatment of abdominal pain, diarrhea, dysentery, infected wound, chronic ulcer, anti-tumoral, anti-inflammatory and anti-allergic [8]. Litchi (Litchi chinensis) of the family sapindaceae is regarded as a primitive group and acts as a plant pathogen [9]. Jackfruit (Artocarpus heterophyllus Lam.) of Moraceae family, is rich in phytochemicals, nutrients and antioxidant activity [10]. Kiwi (Actinidia deliciosa) from the actinidiaceae family is traced back to ancient Chinese civilization is filled with vitamin $\mathrm{C}, \mathrm{K}$ and omega 3 fatty acids [11]. This study aims to show the estimation and concentration of amino acids present in commercially available fruits which are mentioned above.

\section{MATERIALS AND METHODS}

\section{Collection and preparation of the sample}

The fruit samples apricot, jackfruit, pomegranate, litchi, mangustan, jamun, kiwi, dragon fruit were collected from the local market and used for the study.

\section{Preparation}

Ten grams of fruits were washed thoromghly under tap water followed by distilled water and blotted on a blotting paper. Peel was removed, chopped and macerated using mortal and pestle with an equal volume of distilled water. Another sample was prepared by boiling the fruits under steam ( $10 \mathrm{~g}$ for $5 \mathrm{~min}$ ).

\section{Estimation of amino acids by ninhydrin method}

Nihydrin, a powerful oxidizing agent, decarboxylates the alphaamino acids and yields an intensely colored bluish purple product which is colorimetrically measured at $570 \mathrm{~nm}$.

\section{Materials required}

Ninhydrin: $0.4 \mathrm{~g}$ of stannous chloride was dissolved in $250 \mathrm{ml}$ of $0.2 \mathrm{M}$ citrate buffer ( $\mathrm{pH} 5.0$ ). This solution was then added to $10 \mathrm{~g}$ of ninhydrin in $250 \mathrm{ml}$ of 2-methoxyethanol.

Diluents Solution: The diluent solution was prepared by mixing water and n-propanol.

Citrate Buffer: 0.2M Citrate buffer solution at pH 5.0 was prepared.

Leucin stock standard and working solution: $10 \mathrm{ml}$ of the stock leucine solution was diluted to $100 \mathrm{ml}$ with distilled water in a standard flask ( $1 \mathrm{ml}$ of this solution contains $100 \mu \mathrm{g}$ leucine).

\section{Procedure}

Into a serious of test tubes, $0.2,0.4,0.6,0.8$ and $1 \mathrm{ml}$ of the working standard solution was pipetted out. In another set of test tubes, 0.2 
$\mathrm{ml}, 0.4 \mathrm{ml}$ and $0.6 \mathrm{ml} 0.8$ and $1 \mathrm{ml}$ of boil extract after centrifmgation was taken (supernatant used for assay). The volume in all the tubes was made to $1 \mathrm{ml}$ with distilled water. Then $1 \mathrm{ml}$ of water served as the blank. To all tubes, $1 \mathrm{ml}$ of ninhydrin solution was added including blank. The tubes were heated in a boiling water bath for $20 \mathrm{~min}$ after which $5 \mathrm{ml}$ of diluent was added, mixed well and incubated at room temperature for $15 \mathrm{~min}$. The bluish purple colour developed was read at $570 \mathrm{~nm}$ using a colorimeter. The amount of amino acid present in the given sample was calculated using the standard graph drawn by taking the $\mathrm{O}$. $\mathrm{D}$ value in $\mathrm{Y}$-axis and concentration of amino acid in X-axis.

\section{RESULTS AND DISCUSSION}

Amino acids were estimated by Ninhydrin method for all the 8 fruits as fresh samples and boiled samples and the results are have been compared. Graph 1 shows $14.6 \mathrm{mg}$ of amino acid presence in Apricot and $32.5 \mathrm{mg}$ for the boiled sample. In a similar study, it was concluded that $33.3 \%$ of amino acids is present in the apricot juice which is significantly higher compared to many other fruits [12]. In the case of Jamun the raw fruit was significantly high at 78.6 and boiled showed a value of 67 which was quite close. The content of free amino acids changed during ripening and senescence of fruit and Jamun contain a fair amount of amino acids [13]. Dragon fruit had only half the amount of amino acids present in the raw sample compared to jamun which was 31.6, however, the boiled value doubled to 62.2. Not much literature on the presence of amino acids in dragon fruit, however, essential amino acid powder manufactured from dragonfruit is commercially available which indicates the feasibility of extraction of amino acids from the same [14]. Pomegranate was also low at 25.8 in the raw sample and 37.5 with boiled fruit sample. Regarding individual amino acids, the total glutamate, aspartate, pyruvate, and serine-related amino acids were higher in the pomegranate juices compared to aromatic amino acids [15]. Mangustan did not display any significant difference irrespective of raw $(76 \mathrm{mg})$ or boiled $(78 \mathrm{mg})$. Sixteen different amino acids were found in Mangustan fruits, including $\gamma$-aminobutyric acid (GABA), alanine (ALA), isoleucine (ILE), valine (VAL), and glycine (GLY) [16]. Litchi inspite of its water content showed $39 \mathrm{mg}$ of amino acids in the raw sample and $59 \mathrm{mg}$ in the boiled samples. Litchi contains several unusual amino acids disrupt gluconeogenesis and $\beta$-oxidation of fatty acids. Seldom can these amino acids be harmful to the human beings [16]. $784 \mathrm{mg} / \mathrm{l}$ of amino acids in litchi juice with more than 33 kinds of aroma compounds were reported. Jackfruit was close to litchi with $33 \mathrm{mg}$ in the raw and 56.2 in the boiled samples. It was reported that jackfruit are rich in lysine, has high contents of leucine and phenylalanine [17]. Kiwi showed values close to pomogrante with raw samples at $27.9 \mathrm{mg}$ and the boiled samples showed a value of 34 . In other studies also, it was identified that kiwi was a rich source of proteins which clearly indicates that it is made of rich sequence of 152 amino acids [18].

From the above study it is evident that for most of the values, the boiled samples show a higher amount of amino acid content that the raw samples amidst the tropical fruits used in this study. The limiting essential amino acids in a food are determined by relating their concentrations in that food to their concentrations in a reference protein.

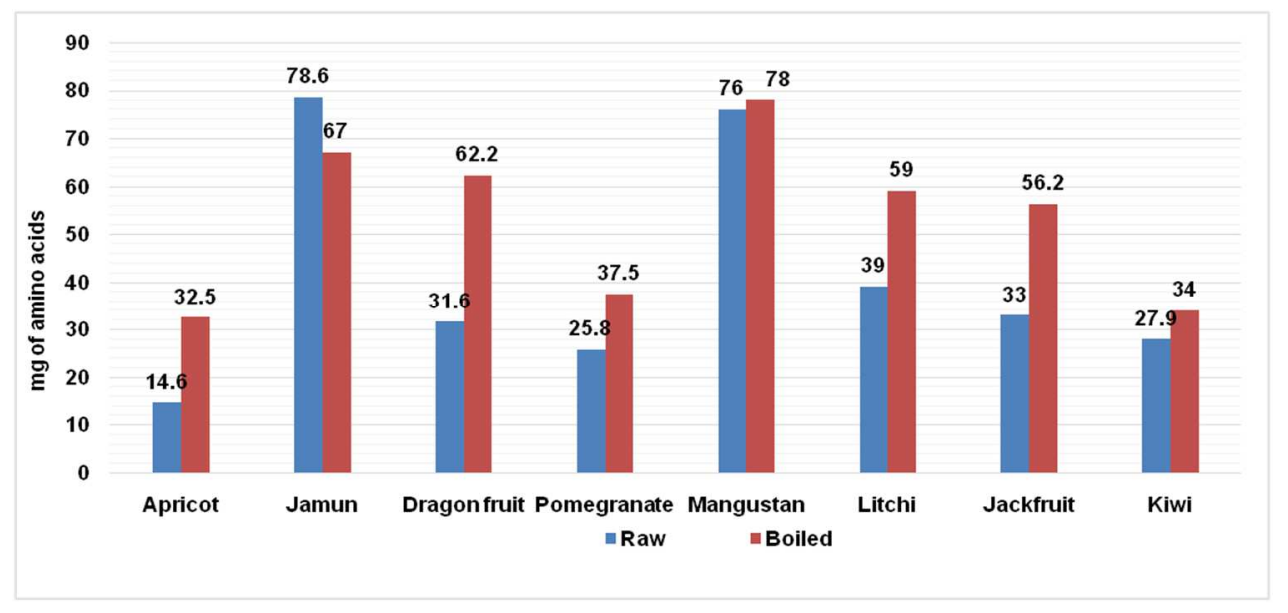

Graph 1: Amount of aminoacids in different fruits

\section{CONCLUSION}

It can be concluded that extensive research on amino acids in boiled fruits and reason as to what increases the measure of the same needs to be conducted. From the current study, it is evident that unlike water soluble vitamins and other minerals which may lose its potential on boiling is not the case with the chosen 8 tropical fruits. Some of our fruits have a good balance of the essential amino acids and they can provide significant sources of protein in our diet.

\section{AUTHORS CONTRIBUTIONS}

All the author have contributed equally

\section{CONFLICT OF INTERESTS}

Declare none

\section{REFERENCES}

1. Yang J, Yang FM, Sun QY. Study on isolation and neurotrophic activity of polysaccharides from Rosa roxburghii. Chin Pharm J 2006; $40: 980-2$.
2. Liu W, Li SY, Huang XE, Cui JJ, Zhao T, Zhang H. Inhibition of tumor growth in vitro by a combination of extracts from Rosa roxburghiitratt and Fagopyrum cymosum. Asian Pac J Cancer Prev 2012;13:2409-11.

3. Berry RE. Tropical fruits and vegetable as potential protein sources. J Food Technol 1981;10:45-9.

4. Gomez, Encarna, Craig A, Ledbetter. Development of volatile compounds during fruit maturation: characterization of apricot and plum $\times$ apricot hybrids. J Sci Food Agric 1997;74:541-6.

5. Shahnawaz, Muhammad, Sheikh SA, Nizamani SM. Determination of nutritive values of Jamun fruit (Eugenia jambolana) products. Pak J Nutr 2009;8:1275-80.

6. Stintzing, Florian C, Schieber A, Carle R. Betacyanins in fruits from red-purple pitaya, Hylocereus polyrhizus (Weber) britton and rose. Food Chem 2002;77:101-6.

7. Khan N, Afaq F, Kweon MH, Kim K. Oral consumption of pomegranate fruit extract inhibits growth and progression of primary lung tumors in mice. Cancer Res 2007;67:3475-82.

8. Misra, Himanshu. Development and validation of high performance thin-layer chromatographic method for determination of [alpha]-mangostin in fruit pericarp of 
mangosteen plant (Garcinia mangostana L.) using ultraviolet-visible detection. Rec Nat 2009;3:178.

9. Zanariah J, Rehan NJ. Protein and amino acid profiles of some Malaysian fruits. MARDI Res Bull Malaysia 1987;15:1-7.

10. Mann K, Farias CM, DelSol FG, Santos CF. The aminoacid sequence of the glucose/mannose specific lectin isolated from Parkia platycephala seeds reveals three tandemly arranged jacalin related domains. Eur J Biochem 2001; 268:4414-22.

11. D'avino R, Bernardi ML, Wallner M, Palazzo P. Kiwifruit act d 11 is the first member of the ripening related protein family identified as an allergen. Allergy 2011;66:870-7.

12. Asadpoor AM, Ansarin M, Nemati M. Amino acid profile as a feasible tool for determination of the authenticity of fruit juices. Pharm Bull 2014;4:359-62.
13. Noomrio MH, Dahot MU. Nutritive value of Emgenia jambosa fruit. J Islam Acad Sci 1996;9:9-12.

14. Mirdehghan SH, Rahemi M. Seasonal changes of mineral nutrients and phenolics in pomegranate (Punica granatum L.) fruit. Sci Hortic 2007;111:120-7.

15. Setiawan E. Amino acids content in mangosteen fruit as affected by tree ages. Agrovigor 2018;9:33-8.

16. Spencer PS, Palmer VS, Mazumder R. Probable toxic cause for suspected lychee-linked viral encephalitis. Emerg Infect Dis 2015;21:904-5.

17. Zanariah J, Rehan NJ. Protein and amino acid profiles of some Malaysian fruits. MARDI Res Bull Malaysia 1987;15:1-7.

18. Camardella L, Carratore V, Ciardiello MA, Servillo L. Kiwi protein inhibitor of pectin methylesterase amino-acid sequence and structural importance of two disulfide bridges. Eur J Biochem 2000;267:4561-5. 